Check for updates

Cite this: J. Mater. Chem. A, 2018, 6, 6510

Received 11th January 2018

Accepted 11th March 2018

DOI: $10.1039 / c 8 t a 00370 j$

rsc.li/materials-a

\section{High performance nanostructured bismuth oxide- cobaltite as a durable oxygen electrode for reversible solid oxide cells $\uparrow$}

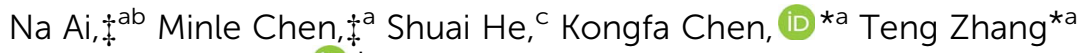 \\ and San Ping Jiang $\mathbb{D}$ *c
}

\begin{abstract}
The high reactivity between bismuth oxide and cobaltite oxygen electrodes is a bottleneck in developing active and reliable bismuth oxide-cobaltite composite oxygen electrodes for solid oxide cells (SOCs). Herein, a $\mathrm{Sr}$-free $\mathrm{Sm}_{0.95} \mathrm{Co}_{0.95} \mathrm{Pd}_{0.05} \mathrm{O}_{3-\delta}(\mathrm{SmCPd})$ oxygen electrode decorated with nanoscale $\mathrm{Er}_{0.4} \mathrm{Bi}_{1.6} \mathrm{O}_{3}$ (ESB) is synthesized and assembled on a barrier-layer-free $\mathrm{Y}_{2} \mathrm{O}_{3}-\mathrm{ZrO}_{2}$ (YSZ) electrolyte film. The cell with the ESB decorated SmCPd composite oxygen electrode exhibits a peak power density of $1.81 \mathrm{~W} \mathrm{~cm}^{-2}$ at $750{ }^{\circ} \mathrm{C}$ and $0.58 \mathrm{~W} \mathrm{~cm}^{-2}$ at $650{ }^{\circ} \mathrm{C}$. More importantly, excellent operating stability is achieved in the fuel cell mode at $600{ }^{\circ} \mathrm{C}$ for $500 \mathrm{~h}$, and in electrolysis and reversible modes at $750{ }^{\circ} \mathrm{C}$ for over $200 \mathrm{~h}$. The results demonstrate the feasibility of applying bismuth oxide-cobaltite composite oxygen electrodes in developing high-performance and durable SOCs.
\end{abstract}

\section{Introduction}

The depletion of fossil fuels and the global climate crisis necessitate the development of innovative technologies to efficiently use renewable energy sources such as nuclear, solar and wind power. Solid oxide cells (SOCs) are such a device of choice for efficient storage and regeneration of renewable sources by alternately operating in solid oxide electrolysis cell (SOEC) and solid oxide fuel cell (SOFC) modes. ${ }^{1-4}$ Manganite and cobaltite based perovskite oxides such as $\mathrm{La}_{0.8} \mathrm{Sr}_{0.2} \mathrm{MnO}_{3+\delta}$ (LSM) and $\mathrm{La}_{0.6} \mathrm{Sr}_{0.4} \mathrm{Co}_{0.2} \mathrm{Fe}_{0.8} \mathrm{O}_{3-\delta}$ (LSCF) are the most investigated oxygen electrodes for SOCs. ${ }^{5-9}$ LSM is predominantly an electronic conductor without ionic conductivity and it is favourable for use at high temperatures $\left(800{ }^{\circ} \mathrm{C}\right.$ and above). On the other hand, cobaltite oxides with mixed ionic/electronic conductivity (MIEC) are ideal for application at intermediate temperatures (600-800 ${ }^{\circ} \mathrm{C}$ ). However, the surface segregation of Sr-containing cobaltite oxygen electrodes and the combination of segregated $\mathrm{Sr}$ with volatile species such as chromium and sulphur constitute a major degradation mechanism of SOC stacks. ${ }^{10-17}$ One straightforward means to address this critical issue is to develop

${ }^{a}$ College of Materials Science and Engineering, Fuzhou University, Fuzhou, Fujian 350108, China.E-mail: kongfa.chen@fzu.edu.cn; Teng_Zhang@fzu.edu.cn; Fax: +86 591 22866537; Tel: +8659122866540

${ }^{b}$ Testing Center, Fuzhou University, Fuzhou, Fujian 350108, China

${ }^{c}$ Fuels and Energy Technology Institute, Department of Chemical Engineering, Curtin University, Perth, WA 6102, Australia. E-mail: S.Jiang@curtin.edu.au; Fax: +61 8 9266 1138; Tel: +61892669804

$\dagger$ Electronic supplementary information (ESI) available. See DOI: $10.1039 / \mathrm{c} 8 \mathrm{ta} 00370 \mathrm{j}$

\$ These authors contributed equally.
Sr-free cobaltite electrodes, ${ }^{18}$ such as $\mathrm{La}(\mathrm{Co}, \mathrm{Fe})_{x} \mathrm{Pd}_{1-x} \mathrm{O}_{3-\delta} \cdot{ }^{\mathbf{1 9 , 2 0}}$ Recently, we have successfully developed a high performance Sr-free $\mathrm{Sm}_{0.95} \mathrm{CoO}_{3-\delta}$ electrode doped with $5 \% \mathrm{Pd}$ in the B-site of the perovskite structure (SmCPd) and assembled it on a barrier-layer-free $\mathrm{Y}_{2} \mathrm{O}_{3}-\mathrm{ZrO}_{2}$ (YSZ) electrolyte. ${ }^{21}$ The combination of SmCPd with an ion-conducting phase such as Gddoped $\mathrm{CeO}_{2}$ (GDC) leads to remarkably enhanced electrocatalytic activity for the oxygen reduction reaction (ORR). ${ }^{21}$

Cubic bismuth oxides such as Er and Y stabilized bismuth oxides (ESB and YSB) possess excellent surface exchange capability and the highest ionic conductivity among the electrolyte materials of SOCs. ${ }^{22,23}$ However, due to its phase instability in reducing environments, bismuth oxide is mainly applied as an interfacial layer between the electrolyte and oxygen electrode, ${ }^{24-26}$ as well as an active promoter for $\mathrm{LSM}^{\mathbf{2 4 , 2 7 - 3 5}}$ and $\mathrm{Ag}$ electrodes. ${ }^{36-38}$ On the other hand, incorporation of bismuth oxide into cobaltite electrodes is rarely reported, possibly due to the high reactivity between bismuth oxide and cobaltite at low temperatures. ${ }^{\mathbf{2 4 , 3 9 - 4 1}}$ For example, Lee et al. observed significant new phase formation after heat-treating the LSCF-ESB mixture at $850{ }^{\circ} \mathrm{C},{ }^{24}$ while Li et al. reported that LSCF started to react with YSB at $650{ }^{\circ} \mathrm{C}^{41}$ On the other hand, Li et al. incorporated YSB into LSCF scaffolds by infiltration and heat-treatment at a low temperature of $600{ }^{\circ} \mathrm{C}$, leading to a remarkably enhanced electrocatalytic activity for proton conducting SOFCs. ${ }^{\mathbf{4 1}}$

Herein, we report the development of a nanostructured ESB decorated Sr-free SmCPd composite oxygen electrode, which is applied on a barrier-layer-free YSZ electrolyte via a direct assembly approach. The incorporation of the highly ion conductive ESB phase is expected to remarkably enhance the electrocatalytic activity of SmCPd, similar to the case of adding 
GDC. ${ }^{21}$ Our recent report has demonstrated the feasibility of preparing ESB decorated LSM at a low temperature of $600{ }^{\circ} \mathrm{C} .{ }^{33}$ Furthermore, the direct assembly approach involves the in situ fabrication of oxygen electrodes under the operating conditions of SOCs (700-800 ${ }^{\circ} \mathrm{C}$ ) by applying electrochemical polarization. ${ }^{\mathbf{4 2 - 4 4}}$ Therefore, the adoption of low temperature powder synthesis and in situ electrode fabrication processes at 600$800{ }^{\circ} \mathrm{C}$ may minimize the potential chemical reaction between ESB and SmCPd, making it possible to develop a bismuth oxide-cobaltite composite oxygen electrode. The results demonstrate that the nanostructured ESB decorated SmCPd oxygen electrode is high performing and stable for running in fuel cell, electrolysis and reversible modes.

\section{Experimental section}

\subsection{Fabrication of supported electrolyte films}

Hydrogen electrode-supported YSZ films were fabricated by slurry spin coating. The hydrogen electrode supports were composed of NiO (J.T. Baker), YSZ (TZ-8Y, Tosoh) and tapioca in a mass ratio of $40: 40: 20$, and the hydrogen electrode functional layer (HEFL) was composed of NiO and YSZ in a mass ratio of $50: 50$. The supported YSZ films were co-fired at $1450{ }^{\circ} \mathrm{C}$ in air for $5 \mathrm{~h}$. The diameter of the as-sintered button cells was $14.5 \mathrm{~mm}$. The thickness of the hydrogen electrode support, HEFL layer and YSZ film was $0.8 \mathrm{~mm}, 14 \mu \mathrm{m}$ and $12 \mu \mathrm{m}$, respectively. The geometric surface area of the oxygen electrode was $0.23 \mathrm{~cm}^{2}$. The detailed fabrication processes are available elsewhere. $^{45,46}$

\subsection{Synthesis of powders and preparation of electrodes}

$\mathrm{Sm}_{0.95} \mathrm{Co}_{0.95} \mathrm{Pd}_{0.05} \mathrm{O}_{3}$ (SmCPd) and $\mathrm{Er}_{0.4} \mathrm{Bi}_{1.6} \mathrm{O}_{3}$ (ESB) powders were synthesized using a modified Pechini method, with the chemicals of $\mathrm{Sm}\left(\mathrm{NO}_{3}\right)_{3} \cdot 6 \mathrm{H}_{2} \mathrm{O}$ (99\%, Sigma-Aldrich), $\mathrm{Co}\left(\mathrm{NO}_{3}\right)_{2}{ }^{-}$ $\cdot 6 \mathrm{H}_{2} \mathrm{O}$ (98.0-102.0\%, Alfa-Aesar), $\mathrm{Pd}\left(\mathrm{NO}_{3}\right)_{2}$ (10 wt\% aqueous solution, Alfa Aesar), $\operatorname{Er}\left(\mathrm{NO}_{3}\right)_{3} \cdot 5 \mathrm{H}_{2} \mathrm{O}$ (99.9\%, Aldrich), $\mathrm{Bi}\left(\mathrm{NO}_{3}\right)_{3} \cdot 5 \mathrm{H}_{2} \mathrm{O}$ (98\%, Sigma-Aldrich), citric acid (CA, 99.5\%, Chem Supply), ethylenediaminetetraacetic acid (EDTA, 99\%, Acros Organics) and ammonia solution (28\%, Ajax Finechem). The metal ions/CA/EDTA was fixed in a molar ratio of $1: 1.5: 1$. The aqueous solution was stirred on a hot plate and the gel was heat-treated at $180{ }^{\circ} \mathrm{C}$ in an oven for $12 \mathrm{~h}$. The SmCPd and ESB powders were calcined at $900{ }^{\circ} \mathrm{C}$ and $600{ }^{\circ} \mathrm{C}$ in air for $2 \mathrm{~h}$, respectively.

40 wt $\%$ ESB decorated 60 wt $\%$ SmCPd (decorated ESBSmCPd) composite powder was prepared using the same modified Pechini method mentioned above. A 0.15 M ESB aqueous precursor solution containing $\operatorname{Er}\left(\mathrm{NO}_{3}\right)_{3}, \mathrm{Bi}\left(\mathrm{NO}_{3}\right)_{3}, \mathrm{CA}$, EDTA and ammonia (the same purities and suppliers as above) was prepared in a beaker. The as-synthesized SmCPd powder was placed into the beaker, magnetically stirred and heated on a hot plate to evaporate the excess water. The solution was stirred continuously until a viscous gel was obtained. The black gel was thoroughly dried at $180{ }^{\circ} \mathrm{C}$ for $12 \mathrm{~h}$ and the resultant ash was ground in an agate mortar, followed by calcination at 600 $750{ }^{\circ} \mathrm{C}$ in air for $2 \mathrm{~h}$ to obtain the decorated ESB-SmCPd composite powder. The details of the decoration process have been described elsewhere. ${ }^{33}$

The ESB-SmCPd powder was combined with an ink vehicle (Fuel Cell Materials) in a mass ratio of $50: 50$ to form an electrode paste. The paste was coated on the YSZ electrolyte films via direct assembly by simply drying at $100{ }^{\circ} \mathrm{C}$ in air for $2 \mathrm{~h}$ without an additional pre-sintering process at a high temperature as in the case of conventional electrode fabrication processes. ${ }^{44,47}$ Pt paste (Gwent Electronic Materials Ltd) was painted on the electrodes as a current collector and heat-treated at $150{ }^{\circ} \mathrm{C}$ in air for $2 \mathrm{~h}$.

\subsection{Cell testing}

The button cells were sealed on ceramic tubes using a sealant (Ceramabond 552, Aremco Products Inc.) and dried at room temperature in air for at least $12 \mathrm{~h}$. Electrochemical polarization curves and impedance spectra of the cells were measured using a Gamry Potentiostat Reference 3000 and Interface 1000 in a temperature range of $600-750{ }^{\circ} \mathrm{C}$. The hydrogen electrode was flowed with $\mathrm{H}_{2}, \mathrm{H}_{2}-\mathrm{H}_{2} \mathrm{O}, \mathrm{H}_{2}-\mathrm{CO}_{2}$ or $\mathrm{H}_{2}-\mathrm{H}_{2} \mathrm{O}-\mathrm{CO}_{2}$ at a rate of 25-50 $\mathrm{ml} \mathrm{min}^{-1}$, and the oxygen electrode was open to static air. Steam was generated using a humidifier and to avoid the condensation, the stainless steel gas line was wrapped with heating tape and the temperature was maintained at $105{ }^{\circ} \mathrm{C}$. The operating stability of the cells was investigated at a constant current density of $0.5 \mathrm{~A} \mathrm{~cm}^{-2}$ at $750{ }^{\circ} \mathrm{C}$ in the fuel cell mode, electrolysis mode and reversible mode and of $0.25 \mathrm{~A} \mathrm{~cm}^{-2}$ at $600{ }^{\circ} \mathrm{C}$ in the fuel cell mode. The impedance spectra were collected with a $10 \mathrm{mV}$ AC signal applied from $100 \mathrm{kHz}$ to $0.01 \mathrm{~Hz}$ under open circuit conditions. Three identical cells were tested to confirm the reproducibility, and the testing history and initial peak power densities are summarized in Table 1.

\subsection{Phase, microstructure and elemental characterization}

The phase of as-synthesized powders was examined using a Bruker D8 Advance X-ray diffractometer with a $\mathrm{Cu} \mathrm{K} \alpha$ X-ray source. The morphologies of ESB and SmCPd powders, the SmCPd electrode and decorated ESB-SmCPd electrodes were characterized using field emission scanning electron microscopy (FESEM, Zeiss Neon 40EsB and Supra-55 Sapphire) combined with energy dispersive spectroscopy (EDS). The morphology and elemental distribution of the decorated ESBSmCPd powder were measured using a high angle annular dark field scanning transmission electron microscope (HAADFSTEM, FEI Titan G2 80-200 TEM/STEM with ChemiSTEM Technology). The powders were mounted on copper grids for the SEM observations. In order to characterize the electrolyte surface after polarization, the oxygen electrodes were removed from the YSZ electrolyte surface by treatment in $32 \% \mathrm{HCl}$ solution at room temperature for $24 \mathrm{~h}$. To investigate the electrode/electrolyte interface, a lamella was milled across the tested ESB-SmCPd/YSZ interface region using an FEI Helios Nanolab G3 CX DualBeam focused ion beam (FIB)-SEM. Microstructural observation and elemental mapping analysis 
Table 1 Testing history and peak power densities (PPDs) of three identical single cells with directly assembled, decorated ESB-SmCPd oxygen electrodes

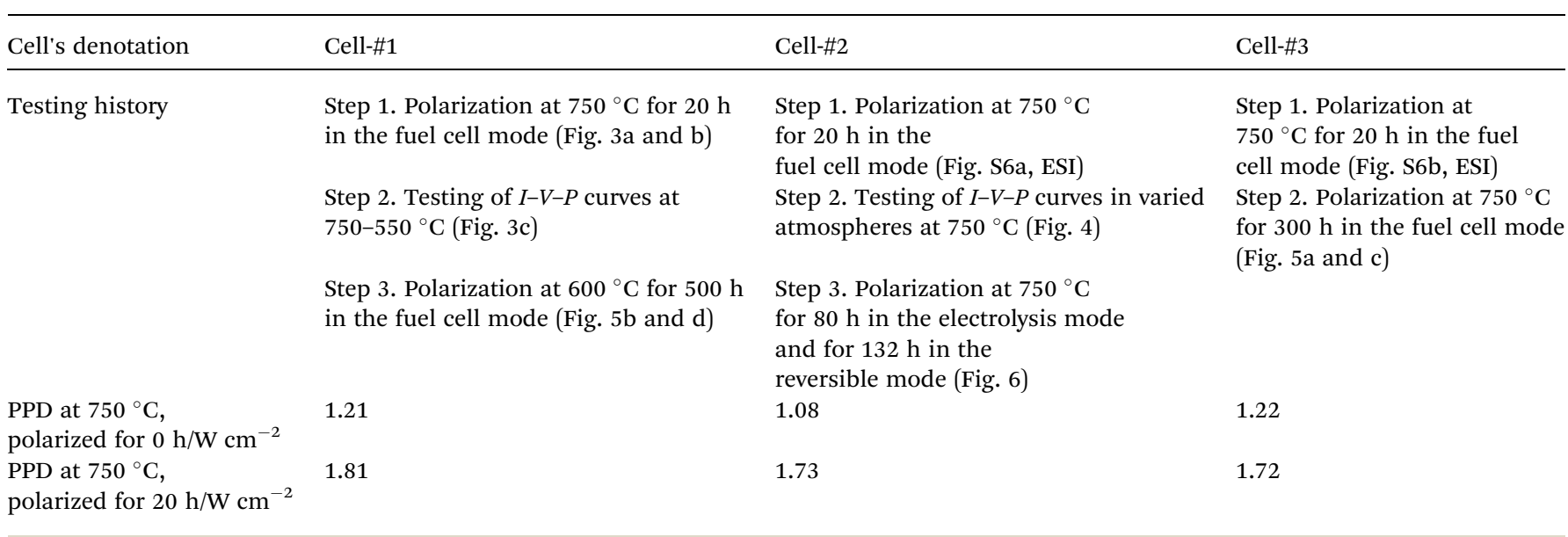

of the lamella were performed using the aforementioned HAADF-STEM.

\section{Results and discussion}

\subsection{Initial phase and microstructure}

Fig. 1 shows the SEM micrographs of SmCPd and ESB powders, the SmCPd electrode, and the ESB-SmCPd electrode and powder. The SmCPd powder calcined at $900{ }^{\circ} \mathrm{C}$ is characterized by spherical particles in a size range of $170-600 \mathrm{~nm}(370 \mathrm{~nm}$ on average, Fig. 1a), while the ESB powder calcined at a lower temperature of $600{ }^{\circ} \mathrm{C}$ is irregularly shaped and in a greater size range of $20-1500 \mathrm{~nm}(630 \mathrm{~nm}$ on average, Fig. 1b). The greater size of the ESB powder than that of the SmCPd powder is due to the low melting point of bismuth oxide $\left(824^{\circ} \mathrm{C}\right) .^{48}$ In the case of the directly assembled ESB-SmCPd electrode, the electrode is characterized by a very fine structure with ESB nanoparticles in a size range of $40-100 \mathrm{~nm}$ (60 nm on average, Fig. 1c), very different from the submicron structure of the directly assembled pristine SmCPd electrode (Fig. 1d and S1, ESI $\dagger$ ). This indicates the successful decoration of SmCPd particles by the nanoscale ESB phase, which is confirmed by the HAADF micrograph and EDS maps of the ESB decorated SmCPd powder (Fig. 1e). The particle size of ESB in the decorated ESB-SmCPd electrode is much smaller as compared to that of the individual ESB powder, indicating that the presence of SmCPd has a remarkable inhibiting effect on the agglomeration and grain growth of ESB. Quantitative EDS analysis on the ESB-SmCPd electrode surface reveals that the relative cation ratios are close to those of the experimental target (Fig. S2, ESI $\dagger$ ).

Fig. $2 \mathrm{a}$ and $\mathrm{b}$ show the XRD patterns and Rietveld refinement of as-synthesized powders. In the case of individual SmCPd and ESB powders, pure orthorhombic perovskite and cubic fluorite phases are obtained without impurity phases, respectively (Fig. 2a). For the decorated ESB-SmCPd powders calcined at $600{ }^{\circ} \mathrm{C}$ and $750^{\circ} \mathrm{C}$, in addition to the expected diffraction peaks from ESB and SmCPd, there are additional peaks related to a new phase of $\mathrm{Bi}_{2} \mathrm{SmO}_{4}$ (Fig. 2a). The formation of the new phase is also confirmed by Raman spectra (Fig. S3, ESI $\dagger$ ). The occurrence of a reaction at a calcination temperature as low as $600{ }^{\circ} \mathrm{C}$ indicates that ESB is highly reactive with SmCPd. The phase identification is also confirmed by the Rietveld refinement on the decorated ESB-SmCPd powder calcined at $750{ }^{\circ} \mathrm{C}$ (Fig. 2b), which estimates the mass ratio of $\mathrm{ESB} / \mathrm{SmCPd} /$ $\mathrm{Bi}_{2} \mathrm{SmO}_{4}$ to be $17: 51: 32$. In such a case, the mass ratio of ESB relative to ESB + SmCPd is $25 \mathrm{wt} \%$, lower than $40 \mathrm{wt} \%$ of the target composition. This is due to the fact that the formation of $\mathrm{Bi}_{2} \mathrm{SmO}_{4}$ needs more Bi from ESB than Sm from SmCPd.

The decorated ESB-SmCPd composite powder was heattreated at $750{ }^{\circ} \mathrm{C}$ in air for $20-300 \mathrm{~h}$, and the XRD patterns are shown in Fig. 2c. After the heat-treatment for $20 \mathrm{~h}$ and longer, $\mathrm{Bi}_{2} \mathrm{SmO}_{4}$ disappears and a new phase of $\mathrm{Sm}_{0.6} \mathrm{Bi}_{1.4} \mathrm{O}_{3}$ is formed, while the SmCPd and ESB phases are still observable. This indicates that $\mathrm{Bi}_{2} \mathrm{SmO}_{4}$ is most likely metastable, as is also confirmed by the presence of a predominant $\mathrm{Sm}_{0.6} \mathrm{Bi}_{1.4} \mathrm{O}_{3}$ phase when we tried to synthesize the $\mathrm{Bi}_{2} \mathrm{SmO}_{4}$ phase using the modified Pechini method (Fig. S4, ESI $\dagger$ ). Nevertheless, $\mathrm{Sm}_{0.6} \mathrm{Bi}_{1.4} \mathrm{O}_{3}$ has been reported to possess reasonable ionic conductivity. ${ }^{49}$

\subsection{Electrochemical performance and stability}

Although $\mathrm{Bi}_{2} \mathrm{SmO}_{4}$ is formed in the as-synthesized ESB-SmCPd composite powder, the ESB-SmCPd composite electrode exhibits outstanding electrocatalytic activity. Fig. 3 shows the polarization performance of a hydrogen electrode-supported YSZ film cell with a directly assembled decorated ESB-SmCPd oxygen electrode (Cell-\#1) as a function of polarization time at $0.5 \mathrm{~A} \mathrm{~cm}^{-2}$ and $750^{\circ} \mathrm{C}$. The cell produces an open circuit voltage of $1.12 \mathrm{~V}$, close to the theoretical value, demonstrating that the YSZ electrolyte film is dense and crack-free with excellent gas impermeability. The initial peak power density (PPD) is $1.21 \mathrm{~W}$ $\mathrm{cm}^{-2}$ and rises to $1.81 \mathrm{~W} \mathrm{~cm}^{-2}$ after polarization at $750{ }^{\circ} \mathrm{C}$ for $20 \mathrm{~h}$ (Fig. 3a). The increase of voltage by the polarization is particularly remarkable in high current regions above $2 \mathrm{~A} \mathrm{~cm}^{-2}$ (Fig. 3a). 

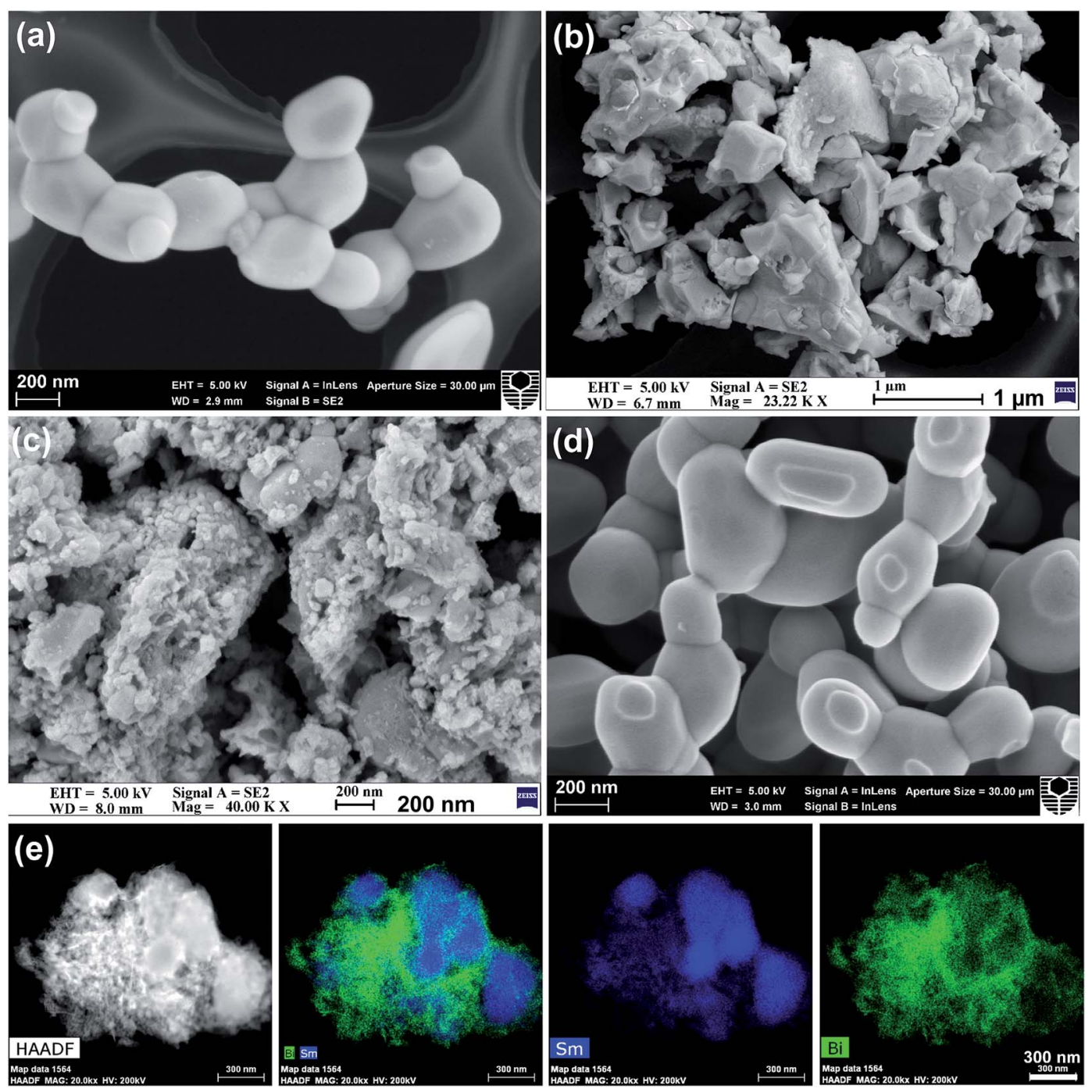

Fig. 1 SEM micrographs of the (a) SmCPd powder calcined at $900^{\circ} \mathrm{C}$, (b) ESB powder calcined at $600{ }^{\circ} \mathrm{C}$, directly assembled (c) decorated ESB$\mathrm{SmCPd}$ electrode and (d) pristine SmCPd electrode after heat-treatment at $600^{\circ} \mathrm{C}$. (e) HAADF micrograph and EDS maps of the decorated ESBSmCPd powder.

The increase of PPD is primarily related to the decrease of electrode polarization resistance $\left(R_{\mathrm{P}}\right)$, as the cell ohmic resistance $\left(R_{\Omega}\right)$ remains constant at $0.07 \Omega \mathrm{cm}^{2}$. The initial $R_{\mathrm{P}}$ is 0.52 $\Omega \mathrm{cm}^{2}$ and decreases to $0.43 \Omega \mathrm{cm}^{2}$ after polarization for $20 \mathrm{~h}$ (Fig. $3 \mathrm{~b}$ ). $R_{\Omega}$ is mainly contributed by the ohmic resistances of the electrolyte, electrodes and contact at the interfaces of electrode/electrolyte and electrode/current collector. The insensitivity of the $R_{\Omega}$ of the decorated ESB-SmCPd electrode to the polarization most likely indicates the instantaneous formation of the electrode/electrolyte interface of the directly assembled ESB-SmCPd electrode during the test. This is very different from the significant decrease of $R_{\Omega}$ in the case of directly assembled pristine SmC and SmCPd-GDC composite electrodes during the polarization. ${ }^{21}$

The impedance spectra consist of two distinctly separable, depressed arcs at a high frequency of $\sim 1000 \mathrm{~Hz}$ and a low frequency of $\sim 0.1 \mathrm{~Hz}$ (Fig. 3b), indicating that there are at least two electrode processes. The electrode processes at high and low frequencies can be divided by fitting the impedance spectra using an equivalent circuit (see the inset of Fig. 3b). In the equivalent circuit, $L$ is related to an inductance, $Q$ and $R$ represent the constant phase element and electrode polarization resistance, respectively, and subscripts $\mathrm{H}$ and $\mathrm{L}$ represent the high and low frequency arcs, respectively. The initial $R_{\mathrm{H}}$ and $R_{\mathrm{L}}$ are 0.29 and $0.23 \Omega \mathrm{cm}^{2}$, and decrease to 0.22 and $0.21 \Omega \mathrm{cm}^{2}$ after polarization at $750{ }^{\circ} \mathrm{C}$ for $20 \mathrm{~h}$, respectively. Plenty of evidence including our previous studies has demonstrated that the high frequency arc is related to the reaction on the oxygen electrode, while the low frequency arc is related to the reaction on the hydrogen electrode. ${ }^{16,50-52}$ Thus the pronounced decrease of $R_{\mathrm{H}}$ indicates that the increase of cell performance is mainly due to the enhanced electrocatalytic activity of the decorated ESB-SmCPd oxygen electrode during the polarization. The performance enhancement of the oxygen electrode is probably due to the conversion of $\mathrm{Bi}_{2} \mathrm{SmO}_{4}$ to $\mathrm{Sm}_{0.6} \mathrm{Bi}_{1.4} \mathrm{O}_{3}$ during the test at $7500^{\circ} \mathrm{C}$ (see the XRD data in Fig. 2 c). 

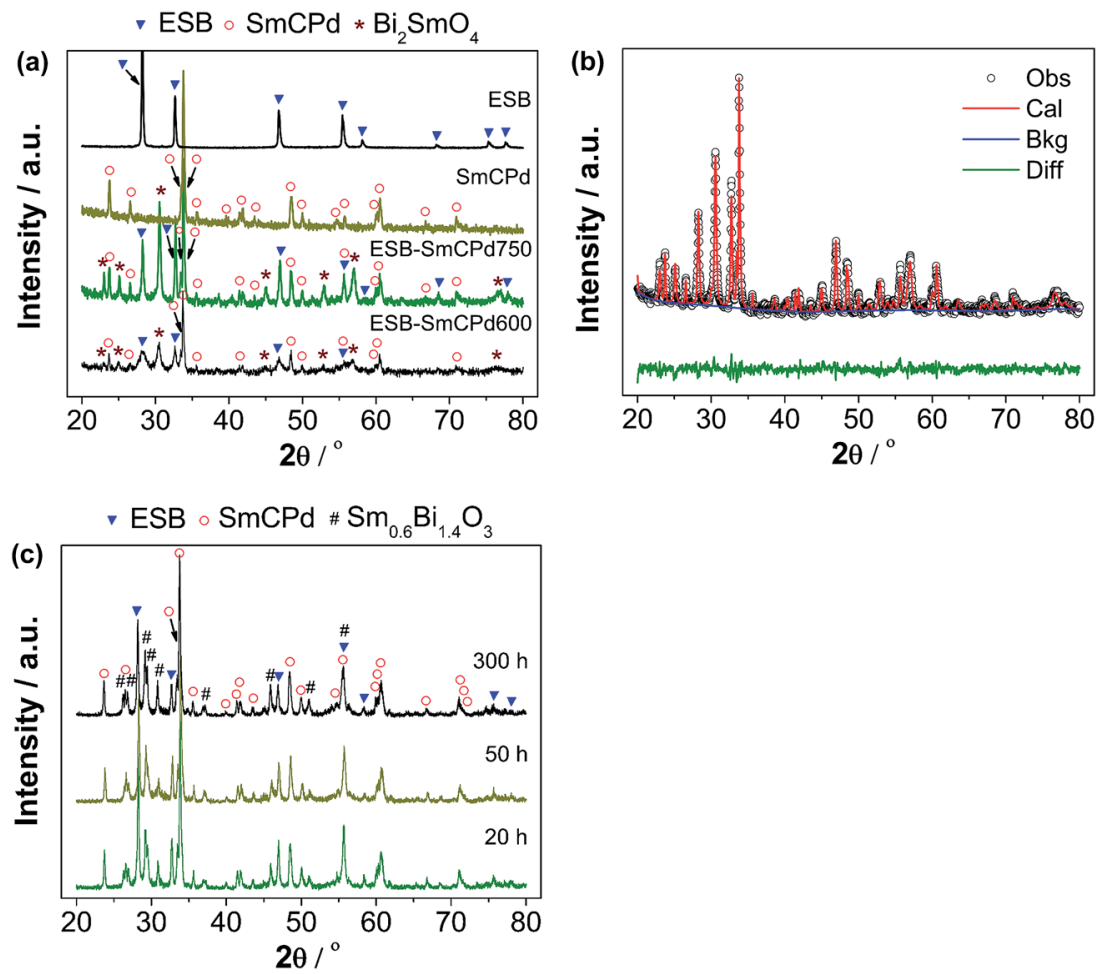

Fig. 2 (a) XRD patterns of ESB and SmCPd powders, and the ESB decorated SmCPd composite powder calcined at 600 and $750{ }^{\circ} \mathrm{C}$ for $2 \mathrm{~h}$ (ESBSmCPd600 and ESB-SmCPd750), (b) Rietveld refinement of the XRD patterns of ESB-SmCPd750, and (c) the ESB decorated SmCPd composite powder after heat-treatment at $750{ }^{\circ} \mathrm{C}$ in air for $20-300 \mathrm{~h}$.
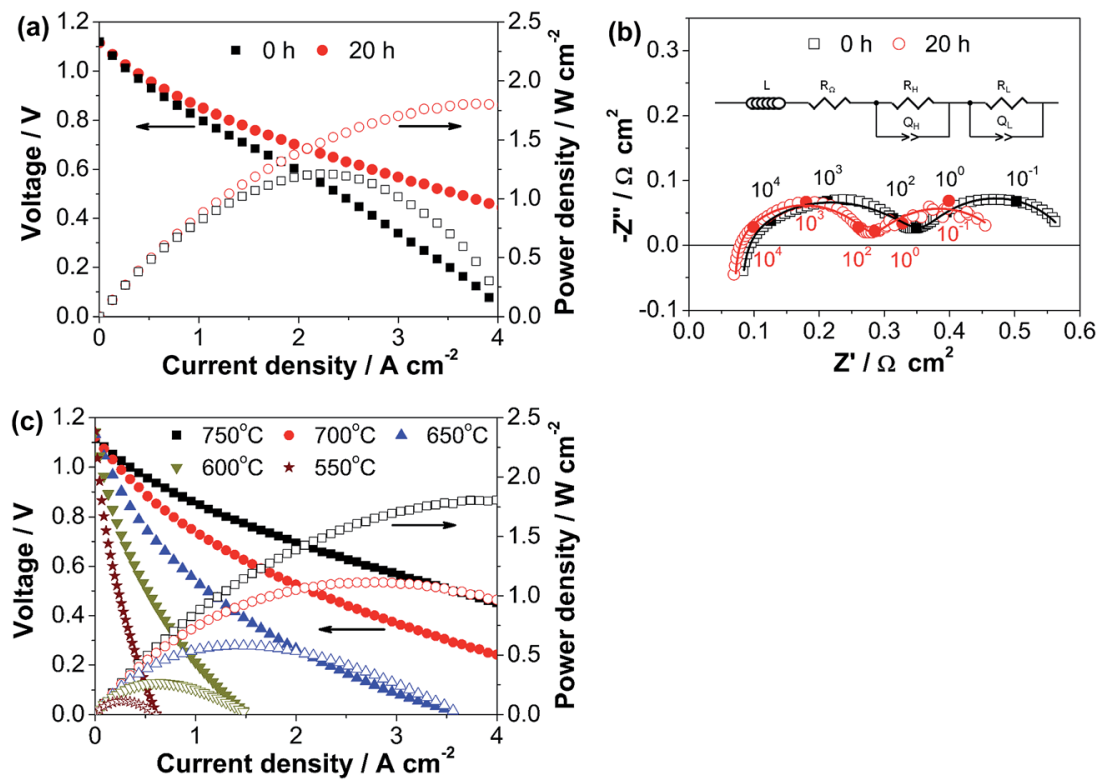

Fig. 3 Performance curves of the cell with the directly assembled, decorated ESB-SmCPd electrode as a function of polarization time at 0.5 A $\mathrm{cm}^{-2}$ and $750^{\circ} \mathrm{C}$. (a) Polarization curves and (b) impedance spectra; the numbers are frequency in $\mathrm{Hz}$ and the lines are fitting data obtained by the equivalent circuit as the inset. (c) Polarization curves as a function of temperature; prior to the test, the cell was polarized at $0.5 \mathrm{~A} \mathrm{~cm}^{-2}$ and $750{ }^{\circ} \mathrm{C}$ for $20 \mathrm{~h}$.

After polarization at $0.5 \mathrm{~A} \mathrm{~cm}^{-2}$ and $750{ }^{\circ} \mathrm{C}$ for $20 \mathrm{~h}$, the cell polarization curves were measured as a function of temperature. The cell produces PPDs of $1.81,1.12,0.58,0.27$ and $0.12 \mathrm{~W}$ $\mathrm{cm}^{-2}$ at $750,700,650,600$ and $550{ }^{\circ} \mathrm{C}$, respectively (Fig. 3c). The PPD of $1.81 \mathrm{~W} \mathrm{~cm}^{-2}$ at $750{ }^{\circ} \mathrm{C}$ is substantially higher than that of $0.60 \mathrm{~W} \mathrm{~cm}^{-2}$ in the case of the directly assembled pristine 

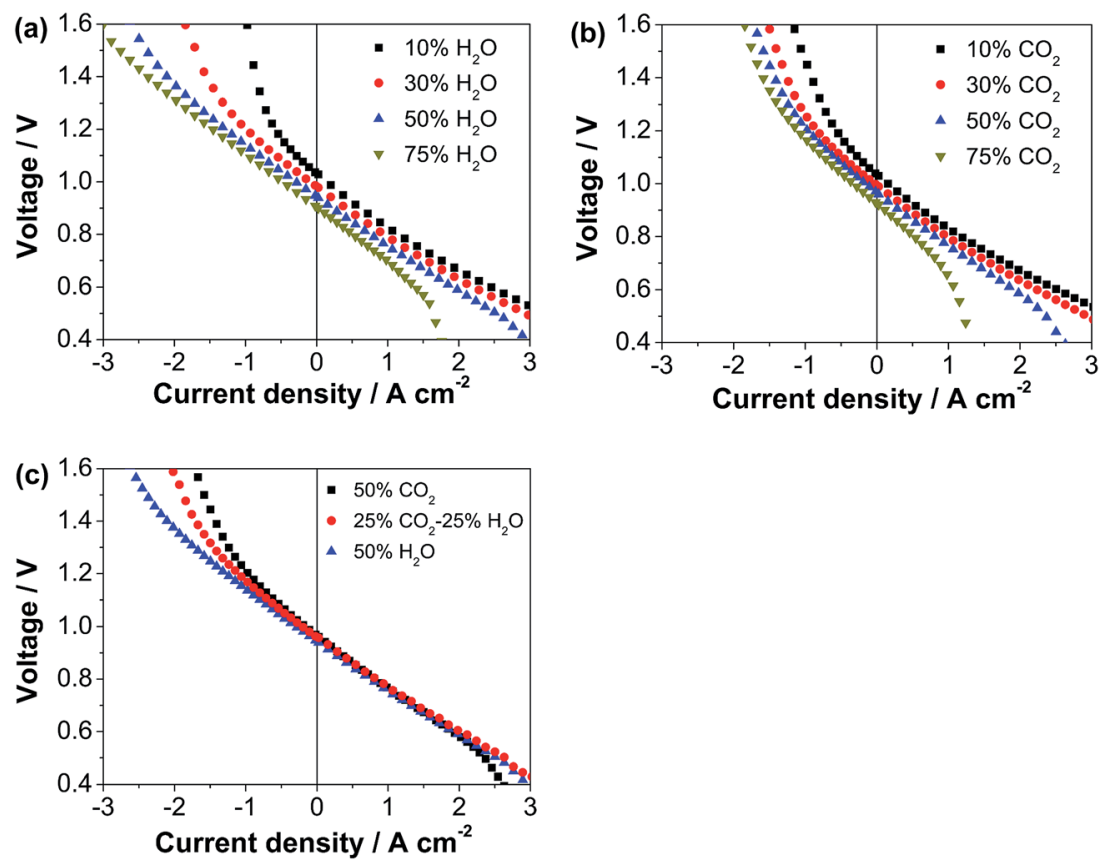

Fig. 4 Polarization curves of the cell with the directly assembled, decorated ESB-SmCPd electrode at $750{ }^{\circ} \mathrm{C}$ : (a) as a function of steam ratio of $\mathrm{H}_{2} \mathrm{O}-\mathrm{H}_{2}$ mixture gas, (b) as a function of the $\mathrm{CO}_{2}$ ratio of the $\mathrm{CO}_{2}-\mathrm{H}_{2}$ mixture gas, and (c) with different feedstock gases.

SmCPd electrode (Fig. S5, ESI† $\dagger$ ), indicating that the decorated ESB nanoparticles are very effective in enhancing the electrocatalytic activity of SmCPd.

Fig. 4 shows the polarization curves of another identical cell (Cell-\#2) with the decorated ESB-SmCPd electrode in fuel cell and electrolysis modes with the hydrogen electrodes exposed to different atmospheres. Prior to the test, the cell was polarized at
$0.5 \mathrm{~A} \mathrm{~cm}^{-2}$ and $750{ }^{\circ} \mathrm{C}$ for $20 \mathrm{~h}$ in the fuel cell mode (Table 1 and Fig. S6a, ESI $\dagger$ ). In the fuel cell mode, the cell voltage decreases with increasing concentration of $\mathrm{H}_{2} \mathrm{O}$ and $\mathrm{CO}_{2}$, and there is an abrupt decrease of voltage at high currents related to concentration polarization when the concentration of $\mathrm{H}_{2} \mathrm{O}$ or $\mathrm{CO}_{2}$ exceeds $50 \%$ (Fig. 4a), due to the excess dilution of reactant $\left(\mathrm{H}_{2}\right)$ for the reaction in the hydrogen electrode. In contrast, in the
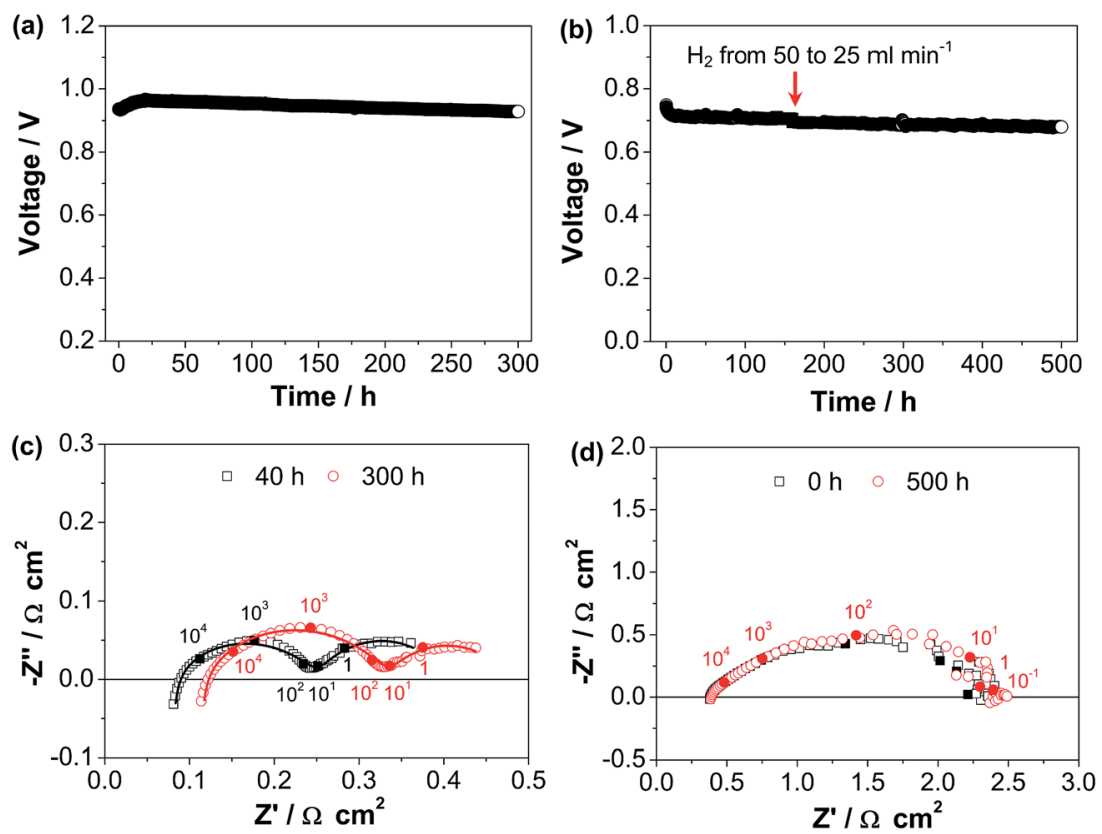

Fig. 5 Stability curves and impedance spectra of the cells with the directly assembled, decorated ESB-SmCPd electrode in the fuel cell mode: (a and c) at $0.5 \mathrm{~A} \mathrm{~cm}^{-2}$ and $750{ }^{\circ} \mathrm{C}$ and $\left(\mathrm{b}\right.$ and d) at $0.25 \mathrm{~A} \mathrm{~cm}^{-2}$ and $600{ }^{\circ} \mathrm{C}$. In (c and d), the numbers are frequency in $\mathrm{Hz}$. During the tests, the hydrogen electrodes were flowed with hydrogen. 
electrolysis mode, the cell performance is enhanced with the increase of concentration of $\mathrm{CO}_{2}$ and in particular $\mathrm{H}_{2} \mathrm{O}$ (Fig. 4b), due to the increased concentration of reactants $\left(\mathrm{CO}_{2}\right.$ and $\left.\mathrm{H}_{2} \mathrm{O}\right)$ for the electrolysis. The performance of co-electrolysis of $25 \%$ $\mathrm{CO}_{2}-25 \% \mathrm{H}_{2} \mathrm{O}-50 \% \mathrm{H}_{2}$ is in between that of electrolysis of $50 \%$ $\mathrm{CO}_{2}-50 \% \mathrm{H}_{2}$ and $50 \% \mathrm{H}_{2} \mathrm{O}-50 \% \mathrm{H}_{2}$ (Fig. 4c). At an electrolysis voltage of $1.3 \mathrm{~V}$, the current density is $1.24,1.45$ and $1.71 \mathrm{~A} \mathrm{~cm}^{-2}$ with $50 \% \mathrm{CO}_{2}-50 \% \mathrm{H}_{2}, \quad 25 \% \mathrm{CO}_{2}-25 \% \mathrm{H}_{2} \mathrm{O}-50 \% \mathrm{H}_{2}$ and $50 \%$ $\mathrm{H}_{2} \mathrm{O}-50 \% \mathrm{H}_{2}$, respectively. It is noted that the electrolysis performance is much less sensitive to the concentration of $\mathrm{CO}_{2}$ than that of $\mathrm{H}_{2} \mathrm{O}$, most likely due to the greater diffusion coefficient of $\mathrm{CO}_{2}$ and poor adsorption capability of $\mathrm{CO}_{2}$ on the $\mathrm{Ni}$ surface. ${ }^{53-55}$ The electrolysis performance of the cell with the ESB-SmCPd electrode is comparable or even superior to that of the cells with other oxygen electrodes, such as mixed LSM-YSZ composites, ${ }^{56,57}$ LSM infiltrated YSZ, ${ }^{58}$ co-synthesized YSBLSM, ${ }^{32}$ and LSCF-GDC composites. ${ }^{59}$

The long-term operating stability of the cell in the fuel cell mode was measured at $0.5 \mathrm{~A} \mathrm{~cm}^{-2}$ and $750{ }^{\circ} \mathrm{C}$ (Cell-\#3) as well as at $0.25 \mathrm{~A} \mathrm{~cm}^{-2}$ and $600{ }^{\circ} \mathrm{C}$ (Cell-\#1), and the results are shown in Fig. 5. In the case of the stability test at $750{ }^{\circ} \mathrm{C}$, the cell voltage increases in the first $20 \mathrm{~h}$ and decreases very slowly by the further polarization up to $300 \mathrm{~h}$ (Fig. 5a). The initial voltage is $0.94 \mathrm{~V}$, and increases to $0.96 \mathrm{~V}$ after polarization for $20 \mathrm{~h}$, but decreases to $0.93 \mathrm{~V}$ after polarization for $300 \mathrm{~h}$. The polarization curves and PPDs of Cell-\#3 during the initial polarization for $20 \mathrm{~h}$ can be seen in Table 1 and Fig. S6b, ESI. $\dagger$ The performance loss after polarization for $20 \mathrm{~h}$ is due to the increase of both $R_{\Omega}$ and $R_{\mathrm{P}} . R_{\Omega}$ and $R_{\mathrm{P}}$ are 0.075 and $0.33 \Omega \mathrm{cm}^{2}$ after polarization for $40 \mathrm{~h}$ and increase to 0.109 and $0.37 \Omega \mathrm{cm}^{2}$ after polarization for $300 \mathrm{~h}$, respectively (Fig. 5c). The impedance spectra are fitted using the aforementioned equivalent circuit (see Fig. 3b). The derived $R_{\mathrm{H}}$ and $R_{\mathrm{L}}$ are 0.18 and $0.15 \Omega \mathrm{cm}^{2}$ after polarization for $40 \mathrm{~h}$, and change to 0.23 and $0.14 \Omega \mathrm{cm}^{2}$ after polarization for $300 \mathrm{~h}$, respectively. Thus the increase of $R_{\mathrm{P}}$ is due to the deteriorated high frequency electrode process which originates from the oxygen electrode as discussed above, indicating that the oxygen electrode is degraded during the polarization at
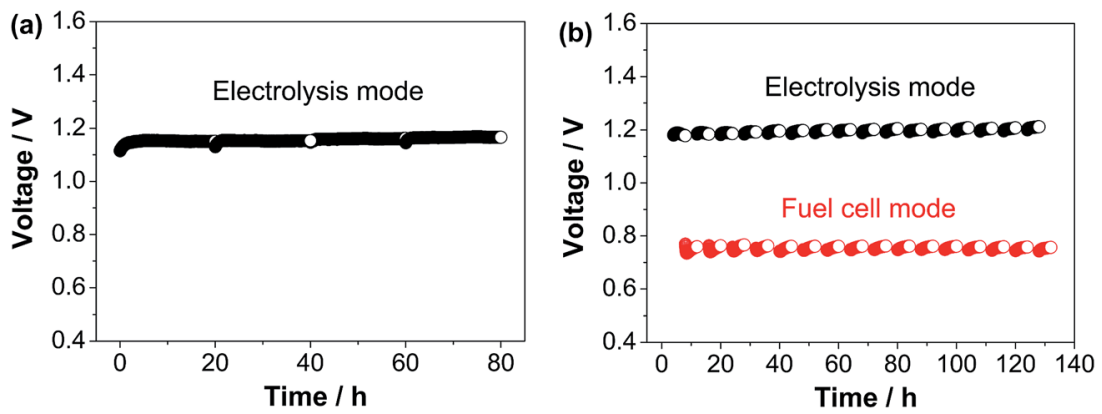

Fig. 6 Stability curves of the cell with the directly assembled, decorated ESB-SmCPd electrode. (a) In the electrolysis mode and (b) in the fuel cell/electrolysis reversible operation mode. During the tests, the hydrogen electrodes were flowed with a $50 \% \mathrm{CO}_{2}-50 \% \mathrm{H}_{2}$ mixture.
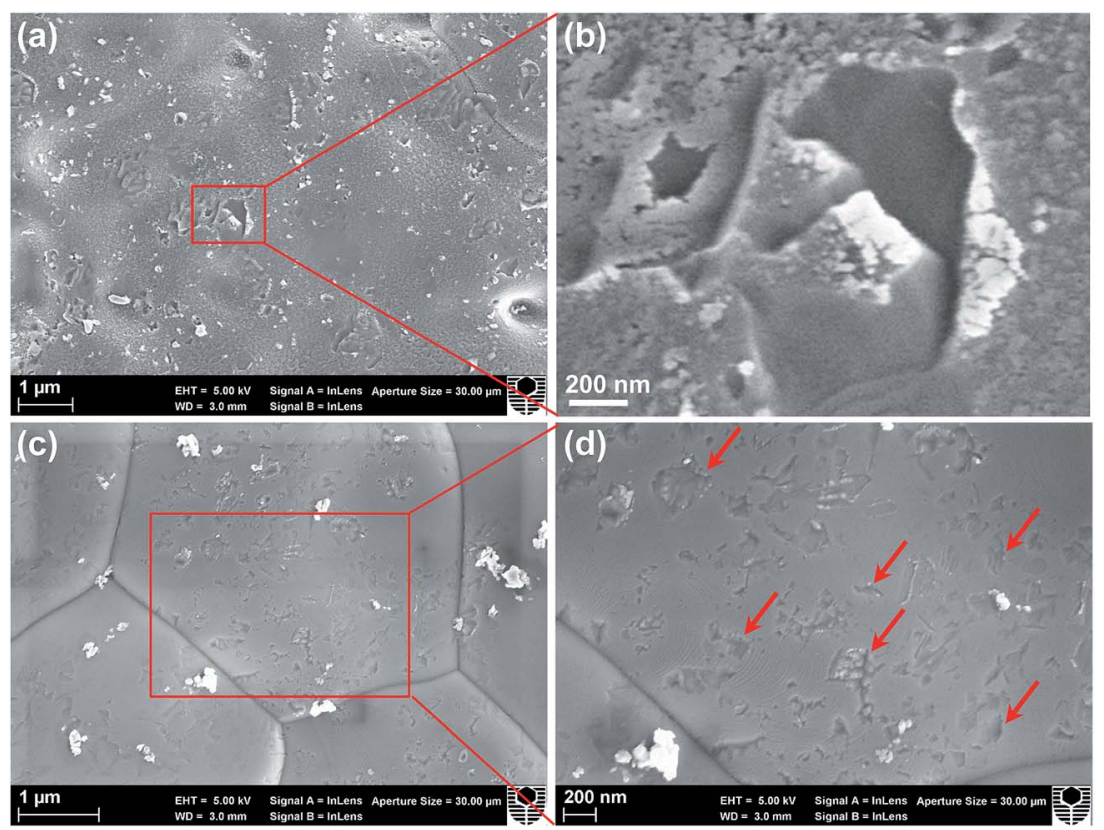

Fig. 7 SEM micrographs of the acid cleaned YSZ electrolyte surface of the cells with directly assembled and decorated ESB-SmCPd electrodes after polarization in the fuel cell mode: ( $\mathrm{a}$ and b) at $0.5 \mathrm{~A} \mathrm{~cm}^{-2}$ and $750{ }^{\circ} \mathrm{C}$ for $300 \mathrm{~h}$ and (c and d) at $0.25 \mathrm{~A} \mathrm{~cm} \mathrm{c}^{-2}$ and $600{ }^{\circ} \mathrm{C}$ for $500 \mathrm{~h}$. 
$750{ }^{\circ} \mathrm{C}$. On the other hand, at a lower operating temperature of $600{ }^{\circ} \mathrm{C}$, the cell is more or less stable during the polarization at $0.25 \mathrm{~A} \mathrm{~cm}^{-2}$ for a longer period of $500 \mathrm{~h}$ (Fig. 5b). Consistently, the impedance spectra are unchanged by the polarization (Fig. 5d). This indicates that under the fuel cell operating conditions, the decorated ESB-SmCPd oxygen electrode is more suitable for operation at a lower temperature of $600{ }^{\circ} \mathrm{C}$.

The operating stability of the cell with the decorated ESBSmCPd electrode (Cell-\#2) was also investigated in electrolysis and reversible modes at a current density of $0.5 \mathrm{~A} \mathrm{~cm}^{-2}$ at $750{ }^{\circ} \mathrm{C}$, and the results are shown in Fig. 6. The cell exhibits good stability during the electrolysis operation for $80 \mathrm{~h}$ (Fig. 6a), much better than the significant performance decay in the case of LSM-based oxygen electrodes in the electrolysis mode. ${ }^{60-65}$ In addition, the reversible operation, i.e., $4 \mathrm{~h}$ in the fuel cell mode and $4 \mathrm{~h}$ in the electrolysis mode in each cycle is more or less stable over 16 cycles for $132 \mathrm{~h}$ (Fig. 6b). The high performance and the excellent operating stability demonstrate that the decorated ESB-SmCPd is a potential active oxygen electrode for durable SOCs.

\subsection{Microstructure and cation interdiffusion at the interface}

Fig. 7 shows the electrolyte surface in contact with the decorated ESB-SmCPd oxygen electrodes after the stability tests at 750 and $600{ }^{\circ} \mathrm{C}$ in the fuel cell mode. In this case, the oxygen electrodes were removed by acid treatment. After polarization at $0.5 \mathrm{~A}$ $\mathrm{cm}^{-2}$ and $750{ }^{\circ} \mathrm{C}$ for $300 \mathrm{~h}$ (Cell-\#3, see Fig. 5a and c), the electrolyte surface is covered by a rough deposition layer and the grain boundaries of the YSZ electrolyte are invisible (Fig. 7a and $\mathrm{b}$ ). On the other hand, after polarization at $0.25 \mathrm{~A} \mathrm{~cm}^{-2}$ and $600{ }^{\circ} \mathrm{C}$ for $500 \mathrm{~h}$ (Cell-\#1, see Fig. $5 \mathrm{~b}$ and d), there is no such deposition layer, as is evident by the relatively clean surface and clear grain boundaries (Fig. 7c and d). The electrode was polarized at $750{ }^{\circ} \mathrm{C}$ for $20 \mathrm{~h}$ prior to the stability test at $600{ }^{\circ} \mathrm{C}$, and therefore, the clean electrolyte surface indicates that there is no severe interfacial reaction between the oxygen electrode and the YSZ electrolyte during such a short period of test at $750{ }^{\circ} \mathrm{C}$. There are also irregularly shaped contact marks on the YSZ electrolyte surface (indicated by the arrows, Fig. 7d), an indication of the in situ formation of the electrode/electrolyte interface under the influence of electrochemical polarization.

\section{(a)}
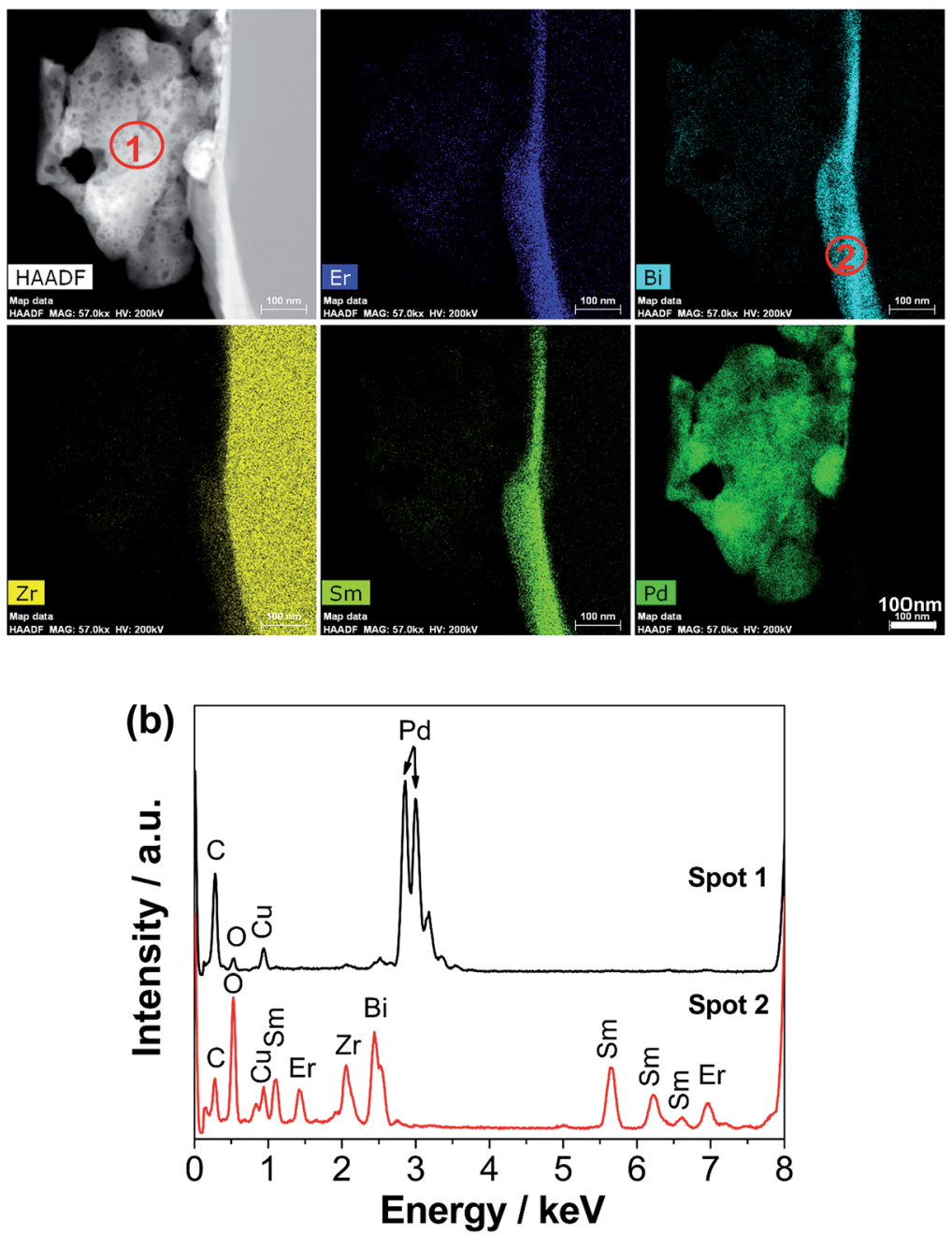

Fig. 8 (a) HADDF micrograph and EDS maps at the electrode/electrolyte interface of the cell with the directly assembled, decorated ESB$\mathrm{SmCPd}$ electrode after polarization at $0.5 \mathrm{~A} \mathrm{~cm}^{-2}$ and $750^{\circ} \mathrm{C}$ for $300 \mathrm{~h}$ in the fuel cell mode, and (b) EDS spectra of the selected spots marked in (a). 
The absence of the deposition layer and the presence of contact marks on the electrolyte surface are consistent with the good operating stability at $600{ }^{\circ} \mathrm{C}$ in the fuel cell mode (see Fig. $5 \mathrm{~b}$ and $\mathrm{d}$ ).

To gain compositional information on the deposition layer on the YSZ electrolyte surface of Cell-\#3 after polarization at $0.5 \mathrm{~A} \mathrm{~cm}^{-2}$ and $750{ }^{\circ} \mathrm{C}$ for $300 \mathrm{~h}$ (see Fig. 7a), FIB-SEM was used to prepare a lamella sample across the electrolyte surface and the STEM-EDS results are shown in Fig. 8. The electrolyte surface is covered by a dense deposition layer with a loose cluster located on the layer (see the HADDF image, Fig. 8a). The cluster is identified as Pd by EDS analysis (spectrum of spot 1, Fig. 8b). Previous XPS analysis has shown that for asprepared SmCPd, Pd exists in the lattice of the SmCPd perovskite structure. ${ }^{21}$ Thus the observation of the Pd phase is because of the occurrence of Pd exsolution out of the SmCPd lattice by the electrochemical polarization. Pd exsolution was also observed in the directly assembled SmCPd-GDC electrode after the cathodic polarization. ${ }^{21}$ The great size of the Pd phase is most likely due to the high tendency of agglomeration and grain growth of $\mathrm{Pd}$ at the high operating temperature of SOCs. ${ }^{66,67}$ The deposition layer has a nominal composition of $\mathrm{Sm}_{0.53} \mathrm{Er}_{0.51} \mathrm{Y}_{0.06} \mathrm{Bi}_{0.44} \mathrm{Zr}_{0.46} \mathrm{O}_{3+\delta}$ (spectrum of spot 2, Fig. 8b), which may belong to a $(\mathrm{Bi}, \mathrm{Zr})_{2} \mathrm{O}_{3+\delta}$ solid solution co-doped with $\mathrm{Sm}$ and Er. There is a lack of the conductivity properties of $(\mathrm{Bi}, \mathrm{Zr})_{2} \mathrm{O}_{3+\delta}$ in the literature, but its formation probably leads to the increase of cell ohmic resistance after polarization at $750{ }^{\circ} \mathrm{C}$ for $300 \mathrm{~h}$ (Fig. 5c).

We have successfully synthesized a nanostructured ESB decorated SmCPd composite electrode, which is directly assembled on a barrier-layer-free YSZ electrolyte film. Although the powder synthesis and cell operation at low temperatures $\left(600-750{ }^{\circ} \mathrm{C}\right.$ ) cannot eliminate the chemical reaction between ESB and SmCPd, forming metastable $\mathrm{Bi}_{2} \mathrm{SmO}_{4}$ and later thermodynamically stable $\mathrm{Sm}_{0.6} \mathrm{Bi}_{1.4} \mathrm{O}_{3}$, the ESB-SmCPd electrode exhibits exceptionally higher electrocatalytic activity in comparison with the pristine SmCPd. This implies that the chemical reaction between ESB and SmCPd is not that harmful as originally expected. More importantly, the partial consumption of ESB and formation of a new $\mathrm{Sm}_{0.6} \mathrm{Bi}_{1.4} \mathrm{O}_{3}$ phase in the composite electrode are beneficial to the stable operation in particular at $600{ }^{\circ} \mathrm{C}$ for $500 \mathrm{~h}$ (Fig. 5b). In the case of ESB, it tends to undergo drastic conductivity degradation at $600{ }^{\circ} \mathrm{C}$ and below, due to the transformation in the arrangement of oxygen vacancies from the disordered state to the ordered state $^{68}$ or due to the transformation from the cubic phase to the rhombohedral phase. ${ }^{69}$ On the other hand, the consequence of losing the highly ion conductive ESB phase is that at a reduced temperature of $650{ }^{\circ} \mathrm{C}$ and below, the cell performance with ESB decorated SmCPd is lower than that with ESB decorated LSM ${ }^{33}$ (PPDs at $650{ }^{\circ} \mathrm{C}: 0.58$ vs. $0.71 \mathrm{~W} \mathrm{~cm}^{-2}$, see Fig. S7, ESI $\dagger$ ). This is most likely due to the higher activation energy for the electrocatalytic reaction on decorated ESBSmCPd than on decorated ESB-LSM (Fig. S8 and S9, ESI $\dagger$ ). In the decorated ESB-LSM electrode, ESB is retained due to its chemical compatibility with LSM. ${ }^{33}$

\section{Conclusions}

Nanostructured ESB decorated SmCPd is investigated as a potential oxygen electrode for SOCs and directly assembled on a barrier-layer-free YSZ electrolyte film. A metastable $\mathrm{Bi}_{2} \mathrm{SmO}_{4}$ phase is formed in the decorated ESB-SmCPd and is transformed to $\mathrm{Sm}_{0.6} \mathrm{Bi}_{1.4} \mathrm{O}_{3}$ after dwelling at $750{ }^{\circ} \mathrm{C}$. The presence of $\mathrm{Sm}_{0.6} \mathrm{Bi}_{1.4} \mathrm{O}_{3}$ in the decorated ESB-SmCPd oxygen electrode has no detrimental effect on the electrode activity, as the cells with the directly assembled ESB-SmCPd oxygen electrodes exhibit exceptionally high electrocatalytic activity and operating stability for power generation and high temperature electrolysis, with excellent stability at $600{ }^{\circ} \mathrm{C}$ for $500 \mathrm{~h}$ in the fuel cell mode, and in electrolysis and reversible modes at $750{ }^{\circ} \mathrm{C}$ for over $200 \mathrm{~h}$. The present study demonstrates the feasibility of developing a Sr-free cobaltite oxygen electrode combined with bismuth oxide for active and stable SOCs.

\section{Conflicts of interest}

There are no conflicts to declare.

\section{Acknowledgements}

The project was supported by the Fuzhou University Qishan Scholarship Program (XRC-17010), the National Natural Science Foundation of China (51672045 and U1732155), the Natural Science Foundation of Fujian Province (2018J01678), the Testing Fund of Fuzhou University (2018T002), and the Australian Research Council under the Discovery Project Scheme (DP150102044, DP150102025, DP180100568 and DP180100731). The authors thank Zhenhuan Zheng for XRD analysis, and acknowledge the facilities, scientific and technical assistance of the Curtin University Microscopy \& Microanalysis Facility and UWA Centre for Microscopy, Characterisation and Analysis, both of which are funded by the University, State and Commonwealth Governments.

\section{References}

$1 \mathrm{~J} . \quad$ T. S. Irvine, D. Neagu, M. C. Verbraeken, C. Chatzichristodoulou, C. Graves and M. B. Mogensen, Nat. Energy, 2016, 1, 15014.

2 M. A. Laguna-Bercero, J. Power Sources, 2012, 203, 4-16.

3 S. D. Ebbesen, S. H. Jensen, A. Hauch and M. B. Mogensen, Chem. Rev., 2014, 114, 10697-10734.

4 B. Yu, W. Q. Zhang, J. M. Xu and J. Chen, Int. J. Hydrogen Energy, 2008, 33, 6873-6877.

5 M. Ni, M. K. H. Leung and D. Y. C. Leung, Int. J. Hydrogen Energy, 2008, 33, 2337-2354.

6 C. Graves, S. D. Ebbesen, M. Mogensen and K. S. Lackner, Renewable Sustainable Energy Rev., 2011, 15, 1-23.

7 Y. Zheng, J. Wang, B. Yu, W. Zhang, J. Chen, J. Qiao and J. Zhang, Chem. Soc. Rev., 2017, 46, 1427-1463.

8 C. W. Sun, R. Hui and J. Roller, J. Solid State Electrochem., 2010, 14, 1125-1144.

9 S. P. Jiang, J. Mater. Sci., 2008, 43, 6799-6833. 
10 H. Ding, A. V. Virkar, M. Liu and F. Liu, Phys. Chem. Chem. Phys., 2013, 15, 489-496.

11 G. Vovk, X. Chen and C. A. Mims, J. Phys. Chem. B, 2004, 109, 2445-2454.

12 J. Kuyyalil, D. Newby, J. Laverock, Y. Yu, D. Cetin, S. Basu, K. Ludwig and K. Smith, Surf. Sci., 2015, 642, 33-38.

13 Y. Liu, K. Chen, L. Zhao, B. Chi, J. Pu, S. P. Jiang and L. Jian, Int. J. Hydrogen Energy, 2014, 39, 15868-15876.

14 N. Ni, S. J. Cooper, R. Williams, N. Kemen, D. W. McComb and S. J. Skinner, ACS Appl. Mater. Interfaces, 2016, 8, 17360-17370.

15 N. Ni and S. Skinner, Solid State Ionics, 2016, 288, 28-31.

16 K. Chen, N. Li, N. Ai, Y. Cheng, W. D. A. Rickard and S. P. Jiang, ACS Appl. Mater. Interfaces, 2016, 8, 31729-31737.

17 Y.-L. Huang, A. M. Hussain, C. Pellegrinelli, C. Xiong and E. D. Wachsman, ACS Appl. Mater. Interfaces, 2017, 9, 16660-16668.

18 Y. Chen, W. Zhou, D. Ding, M. Liu, F. Ciucci, M. Tade and Z. Shao, Adv. Energy Mater., 2015, 5, 1500537.

19 N. Li, N. Ai, S. He, Y. Cheng, W. D. A. Rickard, K. Chen, T. Zhang and S. P. Jiang, Solid State Ionics, 2018, 316, 38-46. 20 J. Shen, Y. Chen, G. Yang, W. Zhou, M. O. Tadé and Z. Shao, J. Power Sources, 2016, 306, 92-99.

21 N. Ai, N. Li, W. D. Rickard, Y. Cheng, K. Chen and S. P. Jiang, ChemSusChem, 2017, 10, 993-1003.

22 B. Steele, J. Kilner, P. Dennis, A. McHale, M. Van Hemert and A. Burggraaf, Solid State Ionics, 1986, 18, 1038-1044.

23 E. D. Wachsman and K. T. Lee, Science, 2011, 334, 935-939.

24 K. T. Lee, D. W. Jung, H. S. Yoon, A. A. Lidie, M. A. Camaratta and E. D. Wachsman, J. Power Sources, 2012, 220, 324-330.

25 J. Hou, L. Bi, J. Qian, Z. Zhu, J. Zhang and W. Liu, J. Mater. Chem. A, 2015, 3, 10219-10224.

26 D. W. Joh, J. H. Park, D. Kim, E. D. Wachsman and K. T. Lee, ACS Appl. Mater. Interfaces, 2017, 9, 8443-8449.

27 J. Li, S. Wang, X. Sun, R. Liu, X. Ye and Z. Wen, J. Power Sources, 2008, 185, 649-655.

28 Z. Y. Jiang, L. Zhang, L. L. Cai and C. R. Xia, Electrochim. Acta, 2009, 54, 3059-3065.

29 L. Wu, Z. Jiang, S. Wang and C. Xia, Int. J. Hydrogen Energy, 2013, 38, 2398-2406.

30 K. T. Lee, A. A. Lidie, H. S. Yoon and E. D. Wachsman, Angew. Chem., Int. Ed., 2014, 49, 13463-13467.

31 J. Hou, L. Bi, J. Qian, Z. Gong, Z. Zhu and W. Liu, J. Power Sources, 2016, 301, 306-311.

32 J. Yan, Z. Zhao, L. Shang, D. Ou and M. Cheng, J. Power Sources, 2016, 319, 124-130.

33 N. Ai, N. Li, S. He, Y. Cheng, M. Saunders, K. Chen, T. Zhang and S. P. Jiang, J. Mater. Chem. A, 2017, 5, 12149-12157.

34 N. Ai, J.-P. Veder, Y. Cheng, M. Chen, K. Chen, T. Zhang and S. P. Jiang, J. Electrochem. Soc., 2017, 164, F1471-F1477.

35 A. S. Painter, Y.-L. Huang and E. D. Wachsman, J. Power Sources, 2017, 360, 391-398.

36 Z. Wu and M. Liu, J. Am. Ceram. Soc., 1998, 81, 1215-1220.

37 Y. Zhou, Z. Zhang, C. Yuan, J. Li, C. Xia, Z. Zhan and S. Wang, Int. J. Hydrogen Energy, 2013, 38, 16579-16583.

38 C. R. Xia and M. L. Liu, Adv. Mater., 2002, 14, 521-523.
39 V. Kharton, E. Naumovich and V. Samokhval, Solid State Ionics, 1997, 99, 269-280.

40 V. V. Kharton, E. N. Naumovich, A. A. Yaremchenko and F. M. B. Marques, J. Solid State Electrochem., 2001, 5, 160187.

41 G. Li, B. He, Y. Ling, J. Xu and L. Zhao, Int. J. Hydrogen Energy, 2015, 40, 13576-13582.

42 K. Chen, N. Li, N. Ai, M. Li, Y. Cheng, W. D. A. Rickard, J. Li and S. P. Jiang, J. Mater. Chem. A, 2016, 4, 17678-17685.

43 M. Li, K. Chen, B. Hua, J.-l. Luo, W. D. A. Rickard, J. Li, J. T. S. Irvine and S. P. Jiang, J. Mater. Chem. A, 2016, 4, 19019-19025.

44 N. Li, N. Ai, K. Chen, Y. Cheng, S. He, M. Saunders, A. Dodd, A. Suvorova and S. P. Jiang, RSC Adv., 2016, 6, 99211-99219.

45 K. Chen, Z. Lu, N. Ai, X. Huang, Y. Zhang, X. Ge, X. Xin, X. Chen and W. Su, Solid State Ionics, 2007, 177, 3455-3460.

46 K. Chen, X. Chen, Z. Lu, N. Ai, X. Huang and W. Su, Electrochim. Acta, 2008, 53, 7825-7830.

47 S. P. Jiang, J. Electrochem. Soc., 2015, 162, F1119-F1128.

48 N. M. Sammes, G. A. Tompsett, H. Nafe and F. Aldinger, J. Eur. Ceram. Soc., 1999, 19, 1801-1826.

49 M. Drache, S. Obbade, J. Wignacourt and P. Conflant, J. Solid State Chem., 1999, 142, 349-359.

50 N. Ai, K. Chen, S. P. Jiang, Z. Lü and W. Su, Int. J. Hydrogen Energy, 2011, 36, 7661-7669.

51 K. Chen, L. Zhang, N. Ai, S. Zhang, Y. Song, Y. Song, Q. Yi, C.-Z. Li and S. P. Jiang, Energy Fuels, 2016, 30, 1849-1857.

52 M. Riegraf, V. Yurkiv, R. Costa, G. Schiller and K. A. Friedrich, ChemSusChem, 2017, 10, 587-599.

53 Y. Li, P. Li, B. Hu and C. Xia, J. Mater. Chem. A, 2016, 4, 92369243.

54 Z. L. Zhan and L. Zhao, J. Power Sources, 2010, 195, 72507254.

55 Y.-F. Sun, Y.-Q. Zhang, J. Chen, J.-H. Li, Y.-T. Zhu, Y.-M. Zeng, B. S. Amirkhiz, J. Li, B. Hua and J.-L. Luo, Nano Lett., 2016, 16, 5303-5309.

56 T. Liu, Y. Wang, Y. Zhang, S. Fang, L. Lei, C. Ren and F. Chen, Electrochem. Commun., 2015, 61, 106-109.

57 C. Graves, S. D. Ebbesen and M. Mogensen, Solid State Ionics, 2011, 192, 398-403.

58 C. H. Yang, C. Jin, A. Coffin and F. L. Chen, Int. J. Hydrogen Energy, 2010, 35, 5187-5193.

59 M. J. López-Robledo, M. A. Laguna-Bercero, A. Larrea and V. M. Orera, J. Power Sources, 2018, 378, 184-189.

60 J. R. Mawdsley, J. D. Carter, A. J. Kropf, B. Yildiz and V. A. Maroni, Int. J. Hydrogen Energy, 2009, 34, 4198-4207.

61 K. Chen, N. Ai and S. P. Jiang, Int. J. Hydrogen Energy, 2012, 37, 10517-10525.

62 Y. Zhang, K. Chen, C. Xia, S. P. Jiang and M. Ni, Int. J. Hydrogen Energy, 2012, 37, 13914-13920.

63 Y. Zheng, Q. Li, T. Chen, W. Wu, C. Xu and W. G. Wang, Int. J. Hydrogen Energy, 2015, 40, 2460-2472.

64 G. A. Hughes, K. Yakal-Kremski and S. A. Barnett, Phys. Chem. Chem. Phys., 2013, 15, 17257-17262.

65 C. Graves, S. D. Ebbesen, S. H. Jensen, S. B. Simonsen and M. B. Mogensen, Nat. Mater., 2015, 14, 239-244. 
66 N. Ai, K. Chen, S. Liu and S. P. Jiang, Int. J. Hydrogen Energy, 2013, 38, 16569-16578.

67 F. Liang, Z. Wang, J. Sunarso, J. Mao and W. Zhou, Int. J. Hydrogen Energy, 2018, 43, 53-63.
68 N. Jiang, R. M. Buchanan, D. A. Stevenson, W. D. Nix, J.-Z. Li and J.-L. Yang, Mater. Lett., 1995, 22, 215-219.

69 K. Huang, M. Feng and J. B. Goodenough, Solid State Ionics, 1996, 89, 17-24. 